\title{
Mural Nodule
}

National Cancer Institute

\section{Source}

National Cancer Institute. Mural Nodule. NCI Thesaurus. Code C61537.

A solid, sharply demarcated, benign or malignant nodular mass that is attached to the wall of an organ. 